\title{
Problem in the generic delimitation between Alseodaphne, Dehaasia and Nothaphoebe (Lauraceae) in Borneo
}

\author{
S. Julia ${ }^{1}$, E. Soepadmo², W. Yahud ${ }^{1}$
}

\section{Key words}

Alseodaphne

Dehaasia

generic delimitation

Nothaphoebe

Sabah and Sarawak

\begin{abstract}
Alseodaphne, Dehaasia and Nothaphoebe are, morphologically, three closely related genera belonging to the Persea subgroup of the Lauraceae. A total of 214 binomials of the three genera have been published by various authors (International Plant Names Index, March 2007), of which 44 have been attributed to species occurring in Borneo. In revising the Lauraceae for the Tree Flora of Sabah and Sarawak Project, we recognize 40 distinct species (i.e., Alseodaphne 11; Dehaasia 16; and Nothaphoebe 13) for Sabah and Sarawak. These include 34 previously known and 6 undescribed species. Despite many attempts by various authors (Rohwer 1993, 2000, Van der Werff \& Richter 1996, Van der Werff 2001) to clarify the generic delimitation between these three genera, to date there remains to be no satisfactory solution. In the absence of a well-accepted generic delimitation and classification within the Lauraceae as a whole, and for the purpose of preparing revision of the Lauraceae for the Tree Flora of Sabah and Sarawak, we have opted for recognising Alseodaphne, Dehaasia and Nothaphoebe as distinct genera. The distinguishing morphological characters of these three genera, based on specimens from Borneo (Sabah and Sarawak, in particular) are presented.
\end{abstract}

Published on 30 October 2009

\section{INTRODUCTION}

The Lauraceae is one of the largest and important families of trees and shrubs throughout tropical and subtropical forests. About 2 500-3 000 species in 50 genera estimated worldwide consist of many species that are important ecologically and economically (Kostermans 1957, Hutchinson 1964, Burkill 1966, Rohwer 1993, Van der Werff \& Richter 1996).

Based on literature dating back to Blume (1825), about 287 species in 16 genera of the Lauraceae have been reported for Borneo. All these 16 genera are represented in Sabah and Sarawak. At local level, the revision of the Lauraceae for Sabah and Sarawak is still on-going. To date, we recognise 208 species in 16 genera of Lauraceae in Sabah and Sarawak, of which 11 represent undescribed new species.

In the past, many authors have proposed various generic and suprageneric classifications within the Lauraceae. Various morphological and anatomical characters (Miquel 1858, Bentham 1880, Hooker 1886, Pax 1889, Kostermans 1957, 1968, 1973a, b, Hutchinson 1964, Rohwer 1993, Christophel et. al 1996, Van der Werff \& Richter 1996, Van der Werff 2001) as well as selected molecular markers (Rohwer 2000, Chanderbali et al. 2001, Li et al. 2004) have been used to classify and re-classify the genera. As a result, several genera have repeatedly been recognised as distinct or reduced to the synonymy of other genera and placed under similar or different suprageneric groups and/or subgroups within Lauraceae. For example, Miquel (1858), Bentham (1880) and Kostermans (1957) included Nothaphoebe in Persea Mill. while Hooker (1886), Boerlage (1900), Van der Werff (2001) reduced it to Alseodaphne. On the other hand, Bentham (1880), Pax (1889) and Hutchinson (1964) considered Alseodaphne as a synonym of Persea but Hooker (1886), Boerlage (1900),

\footnotetext{
Sarawak Herbarium, Forest Research Centre, 93250 Kuching, Sarawak, Malaysia;

corresponding author e-mail: juliasang@sarawakforestry.com.

${ }^{2}$ Forest Research Institute Malaysia (FRIM), 52109 Kepong, Selangor, Malaysia.
}

Gamble (1912), Ridley (1924) and Kostermans (1973a) recognised Alseodaphne and Persea as two distinct genera.

The problem in generic delimitation within the Lauraceae is not confined to the above mentioned three genera but also prevails in the so-called Laurus/Litsea-group ('Laureae') represented in Borneo by Actinodaphne Nees, Iteadaphne Blume, Lindera Thunb., Litsea Lam., Neolitsea (Benth.) Merr. (Rohwer 1993, Van der Werff 2001, Li et al. 2004, Ng 2005).

In the absence of a well-accepted suprageneric classification and generic delimitation for the Lauraceae as a whole, botanists involved in the revision of the Lauraceae for the Tree Flora of Sabah and Sarawak volume, have adopted the generic delimitation as proposed by Van der Werff (2001), except for the inclusion of Nothaphoebe within Alseodaphne.

Alseodaphne, Dehaasia and Nothaphoebe are morphologically closely similar genera belonging to the Persea subgroup of the Ocotea group of the Lauraceae. Other genera occurring in Borneo that have been placed in the same subgroup include Persea, Phoebe Nees and Caryodaphnosis Airy Shaw (Rohwer 1993).

The genus Alseodaphne was established by Nees (1831) with A. semecarpifolia Nees as the type species. Since then, a total of 98 binomials have been published by various authors (International Plant Names Index 2007). Of these, 11 apply to species occurring in Borneo (Kostermans 1973a). The present study discovered three more entities representing undescribed taxa from Sabah and Sarawak (Yahud et al. in prep.).

Dehaasia was first described by Blume (1836) with D. microcarpa Blume (i.e., synonym for $D$. incrassata (Jack) Kosterm.) as the type species (Kostermans 1973b). A total of 52 binomials have been published for the genus (International Plant Names Index 2007). Of these, seven were attributed to species occurring in Borneo while other species listed in International Plant Names Index (2007) were without indication that the species occurred in Borneo. Kostermans (1973b) recognised 35 species in the genus, distributed from China to New Guinea. Of these, 14 were reported from Borneo. In the present study (Yahud \&

() 2009 Nationaal Herbarium Nederland

You are free to share - to copy, distribute and transmit the work, under the following conditions:

$\begin{array}{ll}\text { Attribution: } & \text { You must attribute the work in the manner specified by the author or licensor (but not in any way that suggests that they endorse you or your use of the work). } \\ \text { Non-commercial: } & \text { You may not use this work for commercial purposes. }\end{array}$

Non-commercia:

No derivative works: You may not alter, transform, or build upon this work

For any reuse or distribution, you must make clear to others the license terms of this work, which can be found at http://creativecommons.org/licenses/by-nc-nd/3.0/legalcode. Any of the above conditions can be waived if you get permission from the copyright holder. Nothing in this license impairs or restricts the author's moral rights. 

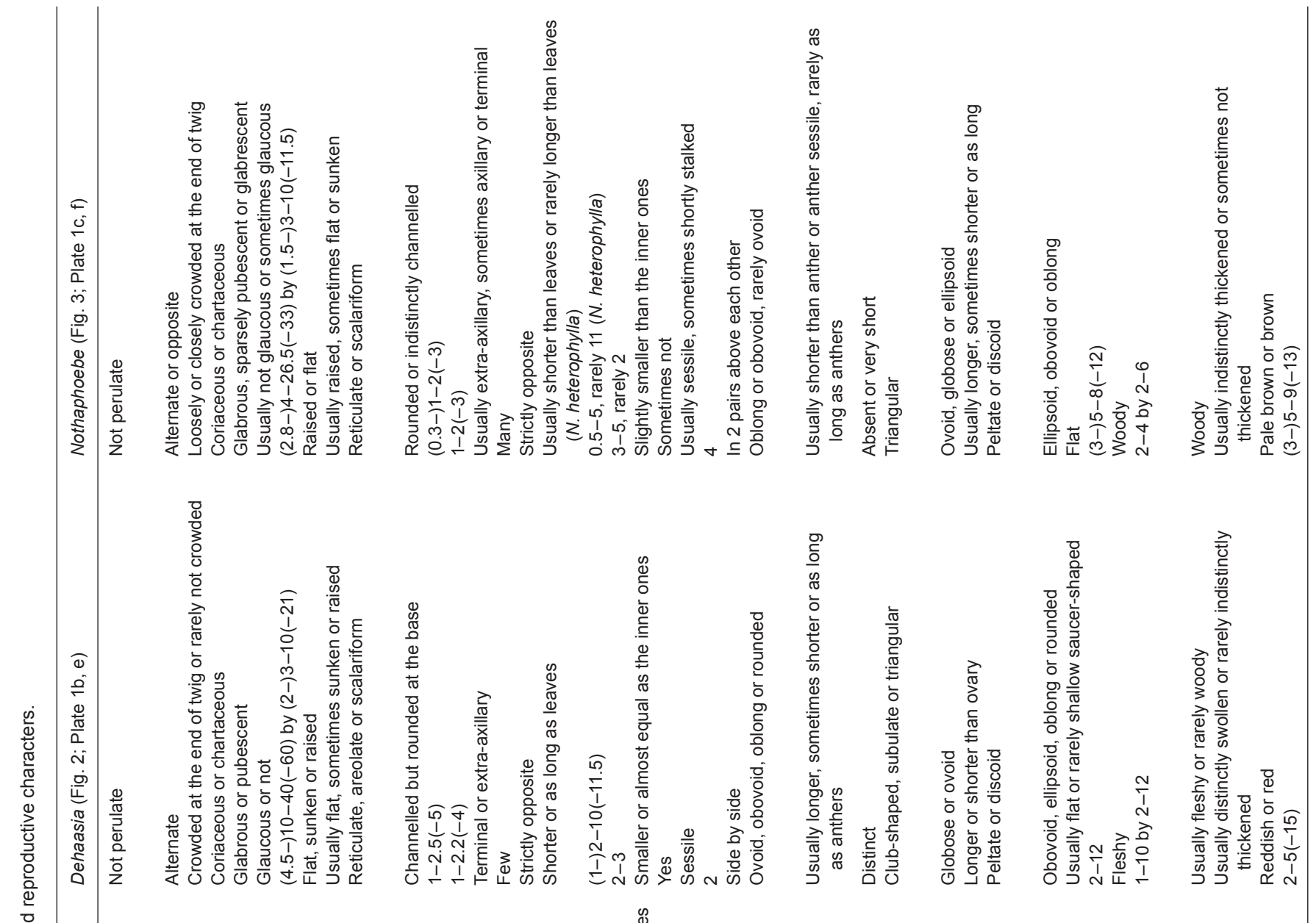

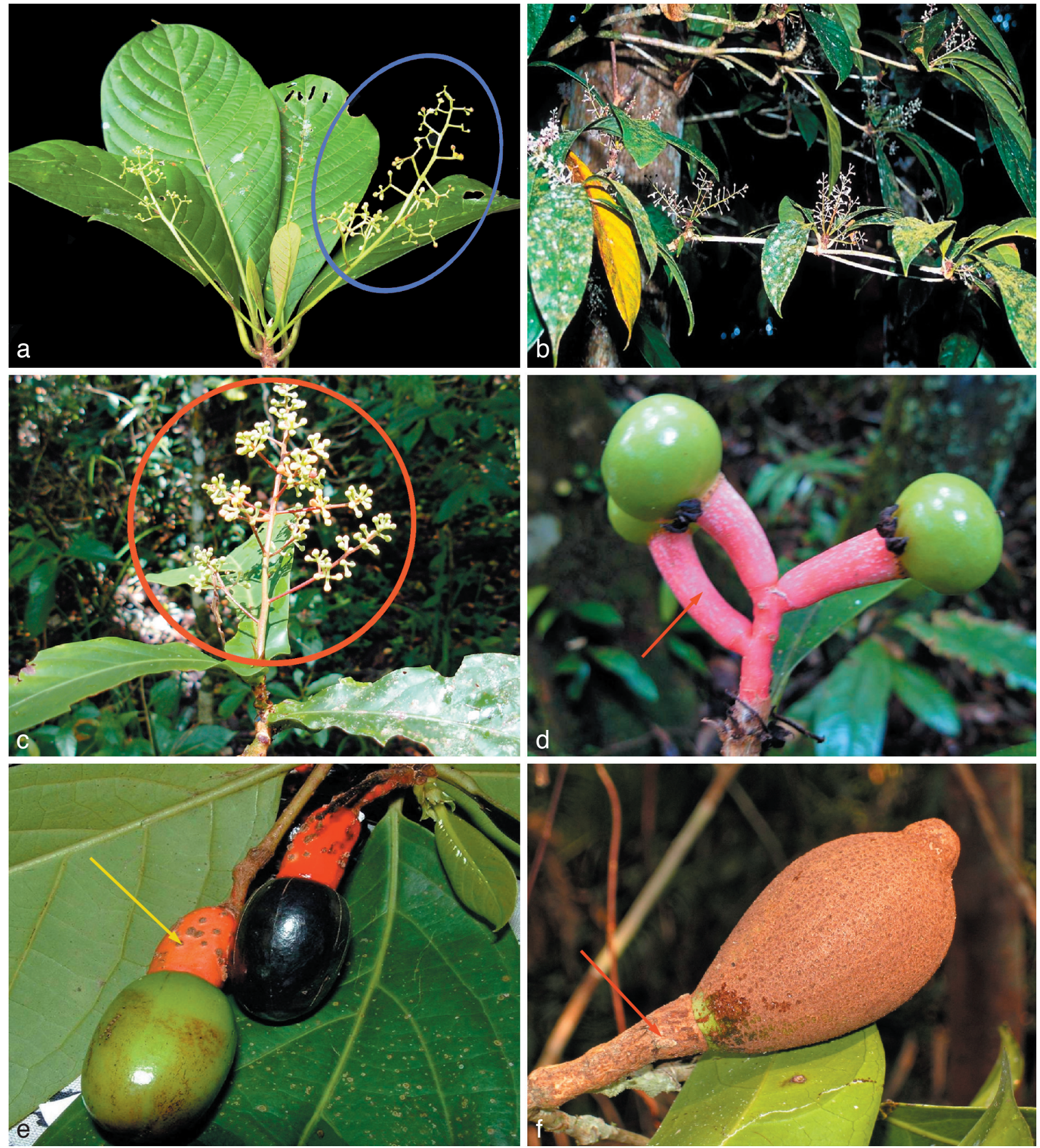

Plate 1 a. Inflorescence of Alseodaphne elmeri; b. inflorescence of Dehaasia brachybotrys; c. inflorescence of Nothaphoebe sarawakensis; d. fruit and pedicel of Alseodaphne borneensis; e. fruit and pedicel of Dehaasia incrassata; f. fruit and pedicel of Nothaphoebe havilandii. @ TFSS Project.

Soepadmo in prep.) we recognise 16 species in Sabah and Sarawak, including two new species.

The genus Nothaphoebe was established by Blume (1851) with N. umbelliflora (Blume) Blume (basionym: Ocotea umbelliflora Blume) as the type species. A total of 45 binomials have been published (International Plant Names Index 2007), of which only two apply to species found in Borneo. Present revision (Julia et al. in prep.) recognises 13 species in Sabah and Sarawak including four new species to be described.

As has been adequately discussed by Rohwer $(1993,2000)$, Van der Werff (2001) and Li et al. (2004), hitherto, the suprageneric classification as well as the generic delimitation within the Lauraceae are largely remain unresolved. Some of the main reasons for this problem are the lack of recent and up-to-date revisions and/or monographs of most of the known genera and that classification based mainly on morphological and anatomical evidence is generally inconclusive and unsatisfactory. The problem is compounded further by the fact that only a few genera have been subjected to molecular studies (e.g., Chanderbali et al. 2001, Li et al. 2004).

This paper is a first report following from a study undertaken by the authors as part of the revision of Lauraceae for the Tree Flora of Sabah and Sarawak Project (Julia et al. in prep., Yahud \& Soepadmo in prep., Yahud et al. in prep.). Its main goal is to highlight the readily observed morphological characters which may be used to distinguish and identify species of Alseodaphne, Dehaasia and Nothaphoebe occurring in Sabah and Sarawak. 

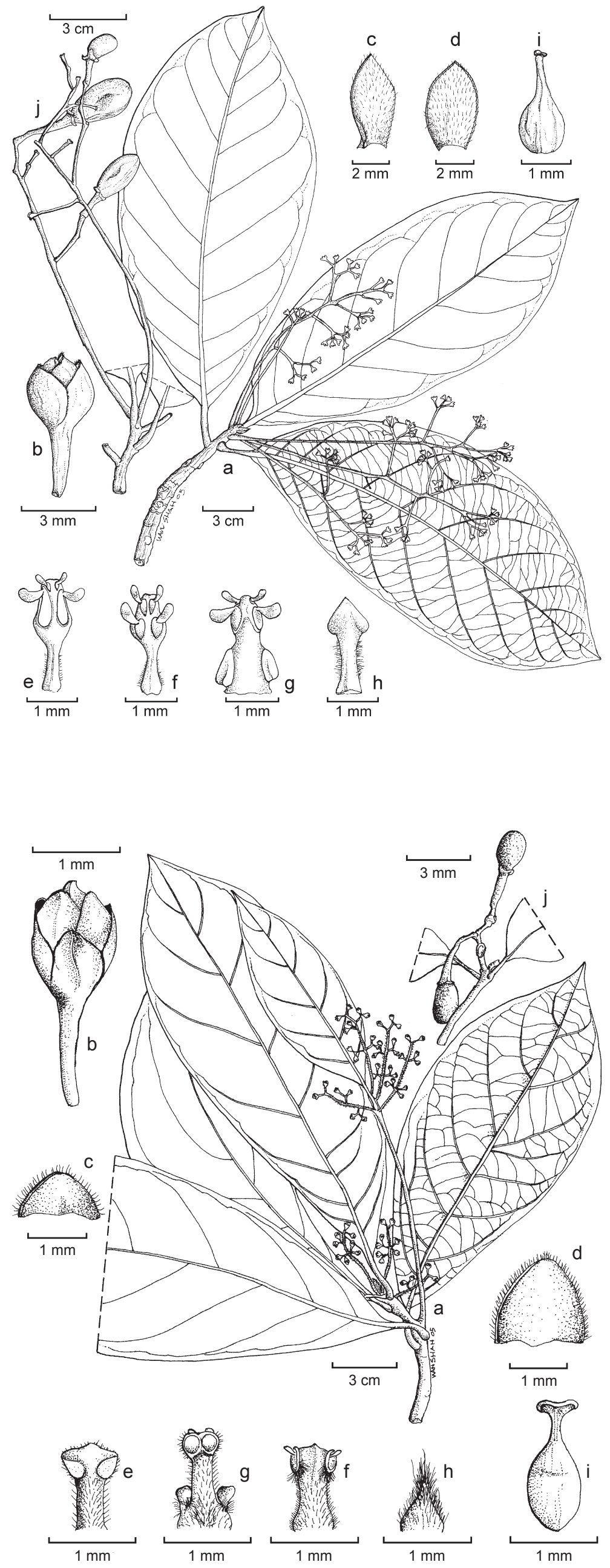

Fig. 1 Alseodaphne elmeri Merr. a. Flowering leafy twig; b. flower bud; c, d. outer and inner perianth lobes; e. first whorl stamen; f. second whorl stamen; g. third whorl stamen with a pair of glands; h. staminode; i. ovary; j. infructescence (a-i: Elmer 21164, j: S 23946). (c) TFSS Project.

Fig. 2 Dehaasia turfosa Korsterm. a. Flowering leafy twig; b. flower bud; c, d. outer and inner perianth lobes; e. first whorl stamen; $f$. second whorl stamen; $g$. third whorl stamen with a pair of glands; h. staminode; i. ovary; j. infructescence (a-i: S 9262, j: Haviland 3090). @ TFSS Project. 


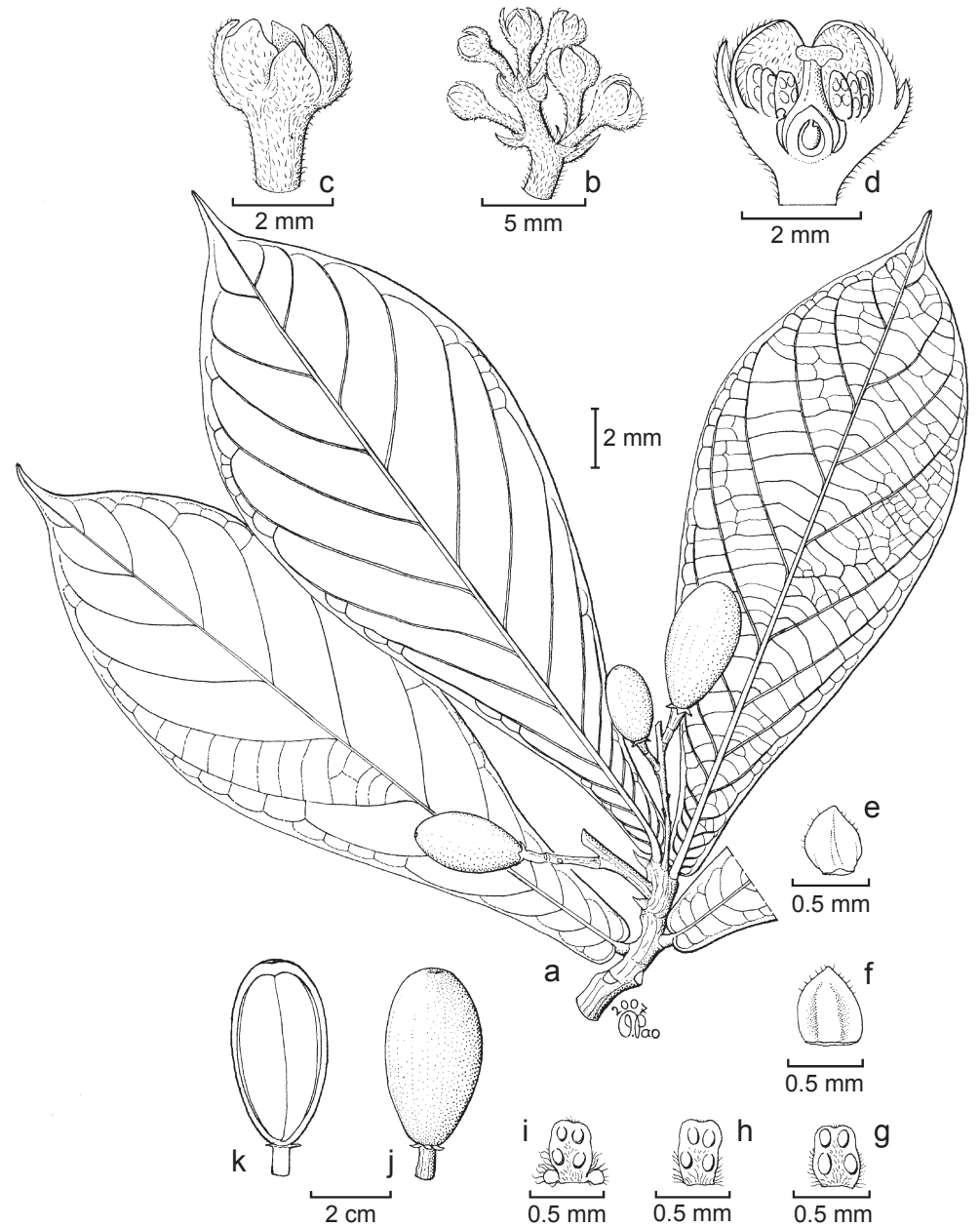

Fig. 3 Nothaphoebe sarawakensis Gamble. a. Fruiting leafy twig; b. terminal/distal part of inflorescence; c. flower bud; $d$. longitudinal section of flower bud; e. outer perianth lobe; f. inner perianth lobe; g. first whorl stamen; h. second whorl stamen; i. third whorl stamen with a pair of glands; j. fruit; k. longitudinal section of fruit (a: $S$ 60316, b-i: S 83384; j, k: S 34612). (C) TFSS Project.

\section{MATERIAL AND METHODS}

A total of about 1500 herbarium specimens of Alseodaphne, Dehaasia and Nothaphoebe collected from Borneo (particularly in Sabah and Sarawak) and its adjacent islands were investigated at the herbaria of the Forest Research Institute Malaysia (KEP), Forest Research Centre, Sandakan, Sabah (SAN), Sabah Parks (KNP), Forest Research Centre, Kuching, Sarawak (SAR), Singapore Botanical Garden (SING), Herbarium Bogoriense (BO) and the Philippines National Herbarium $(\mathrm{PNH})$. Digital images of type specimens were obtained from the websites made available online by The National Herbarium of the Netherlands, University of Leiden Branch (L), The New York Botanical Gardens (NY) and The Royal Botanic Gardens Kew (K). Additional flowering and fruiting specimens were occasionally obtained from the field in Sabah and Sarawak.

\section{RESULT AND DISCUSSION}

\section{Comparative morphology of Alseodaphne, Dehaasia and Nothaphoebe in Borneo}

We selected vegetative and reproductive characters which were comparable and readily observable on the herbarium specimens (Table 1).

Table 1 shows that none of the selected vegetative characters can be used conclusively to distinguish the three genera. On the other hand, a number of characters of the petiole, inflorescence, flower and fruit can, in combination, be utilized to large extent to segregate the three genera. In the past, one or more of the characters mentioned in Table 1 were used by previous authors to identify or distinguish these three genera (e.g., leaves arrangement, colour of lower surface, lateral flowers of terminal cymes, perianth lobes, glands, number of anther locules, arrangement of pollen sacs, filament staminodes, receptacle, fruits and fruit pedicels). Sometimes these characters were used to classify the genera into subfamilies in Lauraceae; in addition, like many authors before, we are still using more or less similar characters of the inflorescences and fruits to distinguish these genera. Nevertheless, additional characters that we find useful to distinguish Alseodaphne, Dehaasia and Nothaphoebe include: 1) the number of flowers per inflorescence; 2) relative length of inflorescence compared to the length of leaves; 3) length of proximal rachis (axis) before the first branching; and 4 ) the number of flowers on the distal part of inflorescence. At this stage and for the revision of these three genera for the Tree Flora of Sabah and Sarawak, we tried to use as many characters as possible to distinguish these genera; however, since we only look at Borneo specimens, variation in the characters across these three genera are possible particularly when one study the genera worldwide.

\section{Morphological similarity and differences between the three genera}

Based on our experience dealing with specimens from Borneo, particularly those collected from Sabah and Sarawak, the characters presented in Table 1 can be used to distinguish Alseodaphne, Dehaasia and Nothaphoebe with some degree of certainty; however, since the differences are mainly based on inflorescences and fruits characters, identification of sterile materials are still quite impossible unless one is familiar with all the species in the genera. 
Similarity - All three genera normally have non-perulate terminal vegetative buds. The leaves are pinnately veined and usually crowded at the end of the upright twig. The texture of the leaf blade varies between species across the three genera even though species of Nothaphoebe generally have smaller and thinner leaf blade compared to those of Alseodaphne and Dehaasia. All three genera have a thyrso-paniculate inflorescence known as Type II by Van der Werff (2001); bisexual and trimerous flowers with 6 perianth lobes arranged in 2 whorls (with the lobes of the outer whorl are smaller than or equal to that of the inner ones), 9 fertile stamens arranged in 3 whorls, 3 staminodes, and ovary seated on a flat or shallow hypanthium (receptacle); and the fruit is 'unprotected', subtended only by a shallow saucer-shaped or flat receptacle.

Differences - Data presented in Table 1 suggest that, except for the number of anther locules (4 vs 2), Alseodaphne is more similar to Dehaasia than to Nothaphoebe. This finding is conform with the suggestion made by Rohwer (1993) but contradicts Van der Werff's (2001) proposal in which Nothaphoebe is treated as a synonym of Alseodaphne.

For the purpose of identifying the genera/species occurring in Borneo (Sabah and Sarawak in particular), the comparative morphological data presented in this paper suggest that the three genera can be distinguished as follows:

Nothaphoebe differs from both Alseodaphne and Dehaasia in its rounded or adaxially only indistinctly channelled petiole; many-flowered inflorescence with shorter proximal axis, distal part with 3-5 flowers, filament of fertile stamen very short or absent, more or less sessile staminodes, woody fruit-receptacle with smaller persisting perianth lobes, woody and not or only slightly thickened brown or pale brown fruit-pedicel.

Most species of Alseodaphne can be distinguished from that of Dehaasia by combination of the following characters: lateral flowers of terminal cymes non-opposite (vs strictly opposite); anther 4-locular (vs mostly 2-locular), except in Alseodaphne oblanceolata with 2-locular anther; fruiting receptacle mostly shallow saucer-shaped (vs mostly flat), except in Alseodaphne borneensis with flat receptacle. In the case whereby one odd character is observed, combinations of majority of the characters take precedence over the single character.

\section{CONCLUSION}

As discussed above, Alseodaphne, Dehaasia and Nothaphoebe can be distinguished by a combination of characters. To certain extent, some of these characters are rather qualitative and argumentative, nevertheless for the above and more pressing practical reasons, botanists involved in the revision of the Lauraceae for the Tree Flora of Sabah and Sarawak have, with a minor exception, adopted the generic delimitation as proposed by Van der Werff (2001). In this context, we have opted to recognize Alseodaphne, Dehaasia and Nothaphoebe as three distinct genera.

Acknowledgements We are extremely grateful to the Malaysian Ministry of Science, Technology and Innovation (MOSTI) for the generous financial support for the Tree Flora of Sabah and Sarawak Project. The Director General of FRIM, the Directors of Forest Departments of Sabah and Sarawak and the Sarawak Forestry Corporation are thanked for their continuous guidance, encouragement and support throughout the project. We would like to thank the Director and the Curator of BM, BO, K, KEP, KNP, L, PNH, SAN, SAR and SING Herbaria for the loan of specimens and facilities rendered during our visits to their respective herbaria. The first author would like to thank the Secretariat of the Flora Malesiana VII Symposium and The Flora of Peninsular Malaysia Project for their funding to attend the Flora Malesiana VII Symposium.

\section{REFERENCES}

Bentham G. 1880. Laurineae. In: Bentham G, Hooker JD (eds), Genera Plantarum, ed. 3: 146-168. London.

Blume CL. 1825. Conspectus generum Laurinaearum Java-Nicarum. Bijdragen tot de Flora van Nederlandsch Indië: 552-575.

Blume CL. 1836. Rumphia 1, 8: 161, t. 44.

Blume CL. 1851. Order Laurineae. Museum Botanicum I, 21: 322-335.

Boerlage JG. 1900. Lauraceae. Handleiding tot de Kennis der Flora van Nederlandsch Indië 3, 1: 115-147.

Burkill IH. 1966. A dictionary of the economic products of the Malay Peninsula: 1588-1542. Ministry of Agriculture, Co-operative, Kuala Lumpur, Malaysia.

Chanderbali AS, Van der Werff H, Renner SS. 2001. Phylogeny and historical biogeography of Lauraceae: evidence from the chloroplast and nuclear genomes. Annals of the Missouri Botanical Garden 88, 1: 104-134.

Christophel DC, Kerrigan R, RowettAl. 1996. The use of cuticular features in the taxonomy of the Lauraceae. Annals of the Missouri Botanical Garden 83: 419-432.

Gamble JS. 1912. Lauraceae. Journal of the Asiatic Society of Bengal. Part 2. Natural History $75: 61-70$.

Hooker JD. 1886. Order CXXVIII. Laurineae. Flora of British India 5: 116-188. Reeve \& Co., London.

Hutchinson J. 1964. Lauraceae. The genera of flowering plants I: 125-143. Clarendon Press, Oxford.

International Plant Names Index. 2007. http://www.ipni.org/ipni (accessed in March 2007).

Julia S, Gadana Alnternational Plant Names Index In prep. Revision of the genus Nothaphoebe in Borneo.

Kostermans AJGH. 1957. Lauraceae. Reinwardtia 4, 2: 193-256.

Kostermans AJGH. 1968. Materials for a revision of Lauraceae I. Reinwardtia 7, 4: 291-356.

Kostermans AJGH. 1973a. A synopsis of Alseodaphne Nees (Lauraceae). Candollea 28: 93-136.

Kostermans AJGH. 1973b. A synopsis of the genus Dehaasia Blume (Lauraceae). Botanische Jahrbücher für Systematik, Pflanzengeschichte und Pflanzengeographie 93, 3: 424-480.

Li J, Christophel DC, Conran JG, Li HW. 2004. Phylogenetic relationships within the 'core' Laureae (Litsea complex, Lauraceae) inferred from sequences of the chloroplast gene matK and nuclear ribosomal DNA ITS regions. Plant Systematics and Evolution 246: 19-34.

Miquel FAW. 1858. Ordo LIV. Laurineae. Flora van Nederlandsch Indië 1 , 1: $888-777$.

Nees von Esenbeck CCG. 1831. Lauraceae. In: Wallich N (ed), Plantae Asiaticae Rariores 2: 71.

$\mathrm{Ng}$ FSP. 2005. Taxonomic notes on Bornean Litsea, Lindera, Neolitsea and Iteadaphne (Lauraceae). Gardens' Bulletin Singapore 57, 2: 217-246.

Pax F. 1889. Lauraceae. In: Engler A, Prantl K (eds), Die natürlichen Pflanzenfamilien III, 2: 106-126. Engelmann, Leipzig.

Ridley HN. 1924. Order CXIX. Laurineae. The Flora of the Malay Peninsula, 3: 75-137. Reeve \& Co., Ltd., London.

Rohwer JG. 1993. Lauraceae. In: Kubitzki K, Rohwer JG, Bittrich V (eds), The families and genera of vascular plants, vol. 2: 366-391. SpringerVerlag, Berlin etc.

Rohwer JG. 2000. Toward a phylogenetic classification of the Lauraceae: Evidence from matK sequences. Systematic Botany 25, 1: 60-71.

Van der Werff H. 2001. An annotated key to the genera of Lauraceae in the Flora Malesiana region. Blumea 46: 125-140.

Van der Werff H, Richter HG. 1996. Toward an improved classification of Lauraceae. Annals of the Missouri Botanical Garden 83: 409-418.

Yahud W, Normaya N, Soepadmo E. In prep. Revision of the genus Alseodaphne in Borneo.

Yahud W, Soepadmo E. In prep. Revision of the genus Dehaasia in Borneo. 